\section{EDITORAL COMMENT}

Milestone. This Review is edited and published in a nation now celebrating the 200th anniversary of its political independence. With predictable contentiousness, scholars have divided over the question of whether they can add anything to the occasion. Some argue that the proper role of the political scientist is to stand outside the dominant ideologies which sustain the state and act as critic and goad in behalf of higher, unrealized ideals. Others maintain that the nation is entitled to command the highest loyalties and best efforts of all its people, not least those among its people privileged to be called to the study and teaching of the arts of statecraft and the duties of citizenship.

This is a useful battle, since it helps scholars to clarify their own views on a matter of the utmost moral urgency. There is such a thing, however, as measure and moderation in the application of even the sternest injunction. Anniversaries and other festive occasions ought to provide moments of relief. On this occasion-and without prejudice to any side in the ongoing controversy about the ordinarily proper stance for the scholar-an editor of a scholarly journal may be pardoned for taking note of certain officially protected conditions of freedom and tolerance that prevail in the United States. It is conditions such as these that make possible the receipt and dissemination of all sorts of ideas about politics, the steady maintenance of untrammeled conversation among scholars and students, and the nurturance of the life of the mind.

Freedom of inquiry and advocacy, within very broad limits, are a part of what American citizens celebrate on the bicentennial of independence. American scholars-and especially political scientists-are perhaps less inclined to celebrate than to use freedoms such as these. It is therefore worth reminding ourselves that not all our colleagues the world around are so free to pursue our calling. It is for their sake, as well as for our own, that we remember the good fortune that permits us to write and publish about politics as our consciences and our knowledge dictate.

Reminder. All new editorial correspondence should go to Professor Charles $O$. Jones, Managing Editor Elect, Department of Political Science, University of Pittsburgh, Pittsburgh, Pennsylvania 15213.

\section{Articles Accepted For Future Publication}

Joel D. Aberbach, University of Michigan and Bert A. Rockman, University of Pittsburgh, "Clashing Beliefs Within the Executive Branch: The Nixon Administration Bureaucracy"
Paul R. Abramson, Michigan State University, "Generational Change and the Decline of Party Identification"

C. Arnold Anderson, University of Chicago, "Conceptual Framework for Political Socialization in Developing Societies"

John A. Armstrong, University of Wisconsin, "Mobilized and Proletarian Diasporas"

John M. Bacheller, Kirkland College, "Lobbyists and the Legislative Process: The Impact of Environmental Constraints"

Richard M. Bank, University of California, Santa Barbara and Steven R. McCarl, University of Denver, "Virtue, Obligation and Politics Revisited"

Robert A. Bernstein, Texas A\&M University, "Divisive Primaries Do Hurt: U.S. Senate Races, 1956-1972"

Steven R. Brown, Kent State University, "Toward An Experimental Analysis of Political Literature"

Charles D. Cary, University of Iowa, "A Technique of Computer Content Analysis of Transliterated Russian Language Textual Materials: A Research Note"

Clarke E. Cochran, Texas Tech University, "Authority and Community: The Contributions of Carl Friedrich, Yves Simon, and Michael Polanyi"

Neal E. Cutler, University of Southern California, "Demographic, Social Psychological, and Political Factors in the Politics of Age: A Call for Research in Political Gerontology"

Barbara Deckard, University of California, Riverside, "Party Realignment and the Transformation of the Political Agenda-The House of Representatives, 1925-1938"

Shaheen F. Dil, Princeton University, "The Cabal in Kabul: Great Power Interaction in Afghanistan

Lowell Dittmer, State University of New York, Buffalo, "Thought Reform and the Cultural Revolution: An Analysis of the Symbolism of Chinese Polemics"

Robert Eyestone, University of Minnesota, "Confusion, Diffusion and Innovation"

Norman I Fainstein, Columbia University and Susan S. Fainstein, Rutgers University, "The Future of Community Control"

Richard F. Fenno, Jr., University of Rochester, "Congressmen in Their Constituencies: An Exploration"

John A. Ferejohn, California Institute of Technology, "On the Decline of Competition in Congressional Elections" 
John V. Gillespie, Dina A. Zinnes, Philip A. Schrodt, G. S. Tahim and Richard Rubinson, Indiana University, "An Optimal Control Model of Arms Races"

R. Kenneth Godwin and W. Bruce Shepard, Oregon State University, "Political Processes and Public Expenditures: A Re-examination Based on Theories of Representative Government"

Robert W. Jackman, Michigan State University,

"Politicians in Uniform: Military Governments and Social Change in the Third World"

Bryan D. Jones, Wayne State University, "Bureaucratic Response to Citizen-Initiated Contacts: Environmental Enforcement in Detroit"

Russell Hardin, University of Pennsylvania, "Hollow Victory: The Minimum Winning Coalition"

Fred M. Hayward, University of Wisconsin, Madison, "A Reassessment of Conventional Wisdom About the Informed Public: National Political Information in Ghana"

Douglas A. Hibbs, Jr., Massachusetts Institute of Technology, "Industrial Conflict in Advanced Industrial Societies"

David K. Hildebrand, University of Pennsylvania, James D. Laing and Howard Rosenthal, Carnegie-Mellon University, "Prediction Analysis in Political Research"

M. Kent Jennings and Gregory B. Markus, University of Michigan, "The Effect of Military Service on Political Attitudes: A Panel Study"

Sam Kernell, University of Minnesota, "Presidential Popularity and Negative Voting: An Alternative Explanation of the Mid-Term Congressional Decline of the President's Party"

Michael S. Lewis-Beck, University of Iowa, "The Relative Importance of Socioeconomic and Political Variables for Public Policy"

Michael Margolis, University of Pittsburgh, "From Confusion to Confusion-Issues and the American Voter (1956-1972)"

Richard D. McKelvey, Carnegie Mellon University and John H. Aldrich, Michigan State University, "A Method of Scaling, With Applications to the 1968 and 1972 Presidential Elections"

Richard D. McKelvey and Peter C. Ordeshook, Carnegie-Mellon University, "Symmetric Spatial Games Without Majority Rule Equilibria"

R. D. McKinlay and A. S. Cohan, University of Lancaster, "The Political, Military, and Economic Performance of Military and Nonmilitary Regime Systems: A Cross-National Aggregate Study"

J. Miller McPherson, Susan Welch, University of Nebraska, and Cal Clark, New Mexico State University, "The Stability and Reliability of
Political Efficacy: Using Path Analysis to Test Alternative Models"

Paul E. Meehl, University of Minnesota, "The Selfish Voter Paradox and the Thrown-Away Vote Argument"

Abraham H. Miller, Louis H. Bolce and Mark Halligan, University of Cincinnati, "The JCurve Theory and the Black Urban Riots: An Empirical Test of Progressive Relative Deprivation Theory Using Both Objective and Perceptual Indicators"

Arthur H. Miller, Warren E. Miller, Alden S. Raine, and Thad A. Brown, University of Michigan, "A Majority Party in Disarray: Policy Polarization in the 1972 Election"

Edward N. Muller, State University of New York at Stony Brook, "Behavioral Correlates of Political Support"

Garrison Nelson, University of Vermont, "Partison Patterns of House Leadership Change, 1789-1976"

Helmut Norpoth, University of Cologne, "Explaining Party Cohesion in Congress: The Case of Shared Policy Attitudes"

Thomas C. Nowak, Waynesburg College and Kay

A. Snyder, Michigan State University, "Politics and Administration: The Philippines Before Martial Law"

Karen Orren, University of California, Los Angeles, "Standing to Sue: Interest Group Conflict in the Federal Courts"

Benjamin I. Page, University of Chicago, "The Theory of Political Ambiguity"

Thomas L. Pangle, Yale University, "The Political Psychology of Religion in Plato's Laws"

James L. Perry, University of California, Irvine and Charles H. Levine, Syracuse University, "An Interorganizational Analysis of Power, Conflict, and Settlements in Public Sector Collective Bargaining"

James H. Qualls, The Johns Hopkins University, "Barber's Typological Analysis of Political Leaders"

David Resnick, Cornell University, "Crude Communism and Revolution"

Neil R. Richardson, University of Texas at Austin, "Political Compliance and U. S. Trade Dominance"

Michael J. Robinson, The Catholic University of America, "Public Affairs Television and the Growth of Political Malaise: The Case of The Selling of the Pentagon"

Barry S. Rundquist, University of Illinois, Urbana, Gerald S. Strom, University of Illinois at Chicago Circle, and John G. Peters, University of Nebraska, "Corrupt Politicians and their Electoral Support: Some Theoretical and Experimental Observations" 
Lester M. Salamon, Duke University, "Economic Power and Political Influence: The Impact of Industry Structure on Public Policy"

Thomas Schwartz, Carnegie-Mellon University, "Collective Choice, Separation of Issues and Vote Trading"

Gerald S. Strom, University of Illinois at Chicago Circle, and Barry S. Rundquist, University of Illinois, Urbana, "A Revised Theory of Winning in House-Senate Conferences"

Peter J. Steinberger, University of California, Riverside, "Hegel as a Social Scientist"

J. Weinberger, Michigan State University, "Science and Rule in Bacon's Utopia: An Intro- duction to the Reading of The New Atlantis"

Lynn T. White III, Princeton University, "Local Autonomy in China During the Cultural Revolution: The Theoretical Uses of an Atypical Case"

Fred H. Willhoite, Jr., Coe College, "Primates and Political Authority: A Biobehavioral Perspective"

Gerald C. Wright, Jr., Florida Atlantic University, "Contextual Models of Electoral Behavior: The Southern Wallace Vote"

Marvin Zetterbaum, University of California, Davis, "Equality and Human Need" 